International Journal of Instruction e-ISSN: 1308-1470 • www.e-iji.net

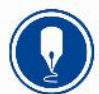

January $2022 \bullet$ Vol.15, No.1

p-ISSN: 1694-609X

pp. 747-764

Article submission code:

20210322014013
Received: 22/03/2021

Revision: 04/08/2021
Accepted: 28/08/2021

OnlineFirst: 14/11/2021

\title{
The Effect of Outdoor Learning Method on Elementary Students' Motivation and Achievement in Geometry
}

\section{Didik Sugeng Pambudi}

Assoc. Prof. Dr., Department of Mathematics Education, Faculty of Teacher Training and Education, University of Jember, Indonesia, didikpambudi.fkip@unej.ac.id

Mastering mathematics in elementary school is essential for students because it provides the foundation to learn the subject at the secondary school and university levels. This study aimed to examine the effect of implementing the Outdoor Learning in Mathematics (OLM) method to increase elementary students' motivation and learning achievements in geometry. This study was carried out at one of the public elementary schools in Jember, East Java, Indonesia using an experimental research design. Participants were 54 grade 4 students consisting of class $4 \mathrm{~A}$ and $4 \mathrm{~B}$, equally divided into the experimental and control groups, respectively. The experimental group was treated in the form of learning geometry topics using the OLM method, while the control group used conventional methods. Data were collected using questionnaires, observation, and tests. The obtained data were analysed using non-parametric statistics with SPSS software. The results showed that students' opinions were very positive and supported the application of the OLM method in elementary schools. In addition, the OLM method triggers the students' motivation, as well as student learning achievements in geometry. Thus, it can be concluded that the Outdoor Learning method has a positive effect on elementary students' motivation and learning achievement in geometry. From these results, it is necessary to conduct further researches involving a large number of participants, develop teacher modules, and incorporate the OLM method into the mathematics curriculum. It is hoped that students will like mathematics more, so that their motivation and learning achievements can be improved.

Keywords: outdoor learning mathematics method, motivation, learning achievement, geometry, learning

\section{INTRODUCTION}

Mathematics is important for the improvement of science and technology, therefore, it needs to be studied by both elementary and secondary school students. In Indonesia, the purpose of learning mathematics in schools is to develop logical, analytical, systematical, critical, and creative thinking abilities (Kemdikbud, 2013). However, it is hoped that students are motivated, to be actively involved in the learning process to realise optimal achievements. All elementary school students need to master basic

Citation: Pambudi, D. S. (2022). The effect of outdoor learning method on elementary students' motivation and achievement in geometry. International Journal of Instruction, 15(1), 747-764. https://doi.org/10.29333/iji.2022.15143a 
mathematics as a provision to continue their lessons at the secondary and college levels. Unfortunately, the majority still have a negative opinion (attitudes) about this subject (Acharya, 2017; Gafoor \& Kurukkan, 2015). According to Herges, Duffield, Martin, \& Wageman (2017), Mata, Monteiro, \& Peixoto (2012), and Pambudi, Budayasa, \& Lukito (2020), there is a significant relationship between students' attitudes and the motivation to learn mathematics. This means that those with positive attitudes are highly motivated to learn mathematics and vice versa (Singh, Granville, \& Dika, 2002; Pambudi, 2020).

Motivation is an important factor for successfull learning (Nalevska, \& Kuzmanovska, 2020). Motivation is a force that triggers students to be actively involved in learning. It is divided into 2 types, namely intrinsic and extrinsic motivation (Ryan \& Deci, 2000; Lepper \& Iyengar, 2005; Ayub, 2010; Anwar, \& Wardhono, 2019). Furthermore, motivation plays an important role in learning mathematics. Students that are highly motivated internally, are usually actively involved in the learning process. Conversely, those that are poorly motivated internally, need the influence of an external force, such as the teacher's teaching methods (Ryan \& Deci, 2000; Lepper \& Iyengar, 2005; Ayub, 2010; Anwar, \& Wardhono, 2019). Teaching method is one of the factors that influence the learning motivation of students. In circumstances, when students actively engage in learning using good teaching method, optimal achievements are realised. Conversely, supposing the conventional teaching method adopted by the teacher does not attract their motivation, thereby, making them passive during learning, with the realization of poor achievements (Adamma, 2018; Akcakin, 2018; Damrongpanit, 2019; Sides \& Cuevas, 2020).

However, poor learning achievement is evident in the indicator used to measure the average national mathematics examination scores from elementary to secondary school students within 2017 and 2020. Unfortunately, the scores were discovered to be below 60 (Kemdikbud, 2020). However, the results of the 2012 PISA (Program for International Student Assessment), Indonesia ranked 64 out of the 65 participating countries with an average math score of 318 (OECD, 2014). In 2015, they ranked 62 out of the 70 participating countries with an average math score of 335 (OECD, 2016). Apparently, in 2018 Indonesia ranked 73 out of the 79 participating countries with an average math score of 379 (OECD, 2019).

The problem of poor learning achievement in mathematics is caused by several factors, including the conventional or mechanistic teaching model adopted in schools (Fauzan, Plomp, \& Gravemeijer, 2013). Mechanistic mathematics learning is characterized by the teacher dominating the class with the lecture method, while the students only receive materials, and then work on the questions assigned by the teacher. This type of method is boring and makes them passive learners, therefore, it needs to be changed or varied with more meaningful processes, such as Outdoor Learning in Mathematics (Beames \& Ross, 2015; Fägerstam \& Blom (2012); Fägerstam, 2014; Richmond, Sibthorp, Gookin, Annarella, \& Ferri, 2017; Thomas, 2018; Waite, 2011).

Outdoor Learning Mathematics (OLM) is designed to be implemented outside the classroom by utilizing the environment as a learning resource that guides students to 
collect data and solve problems, by finding and applying mathematical concepts. This learning method has long been applied in several countries (Beames \& Ross, 2015; Fägerstam, 2014; Richmond et al., 2017; Thomas, 2018; Waite, 2011). Moreover, various studies related to the application of the OLM method have succeeded in triggering students' motivation in learning activities, and achievements, including mathematics (Mygind, 2007; Moss, 2009; Fägerstam \& Blom, 2012; Fägerstam, 2014).

Geometry is one of the topics in elementary school mathematics that studies the concept of triangles, such as isosceles triangles, right triangles, isosceles right triangles, and so on. The low motivation and learning outcomes of students when studying geometry topics are caused by the use of conventional methods by teachers (Pambudi \& Hobri, 2012; Fauzan, et al., 2013; Kivkovich \& Chis, 2016). In fact, generally teachers teach geometry topics in elementary schools using the lecture method, and have not used the OLM method. Based on observations carried out at schools, the teacher uses the whiteboard to explain the lesson, while the students pay attention and solve some exercises (Pambudi \& Hobri, 2012). The question that arises, if the OLM method is able to increase the motivation and learning achievements of mathematics on high school students, does the use of the OLM method also give the same results on the topic of geometry for elementary school students? Therefore, the aim of this study is to examine the effectiveness of the application of the OLM method in boosting students' Learning Motivation (LM), and Learning Achievements of Mathematics (LAM) in geometry. The geometric topic being investigated is an isosceles right triangle, and the use of this concept in calculating the height of the flagpole in the schoolyard.

\section{Research Framework}

Relating to the various literatures reported in the Introduction, the use of framework is, as shown in Figure 1.

\begin{tabular}{|l|l|l|}
\hline $\begin{array}{l}\text { Outdoor Learning } \\
\text { Mathematics (OLM) } \\
\text { method }\end{array}$ & $\begin{array}{l}\text { Learning } \\
\text { Motivation } \\
(\mathrm{LM})\end{array}$
\end{tabular}

Figure 1

Research framework

\section{Research Questions and Objectives}

In accordance with the background of the problem, this research attempts to answer the following questions:

1. How the students' opinion about the application of the OLM method in school?

2. Is the application of the OLM method expected to trigger the students' motivation to learn mathematics?

3. Is there a significant correlation between students' motivation and their learning achievement of mathematics? 
4. Is there a significant difference between the Learning achievement of mathematics of students that learn mathematics with and without the use of OLM method?

The objectives of this study are (1) to describe students' opinion about the application of the OLM method in schools; (2) to determine whether or not the application of the OLM method tends to increase students' motivation to learn mathematics; (3) to determine whether or not a significant correlation between students' motivation and their learning achievement of mathematics; (4) to determine whether there is a significant difference between the LAM of students that learn mathematics with and without the use of OLM method.

\section{METHOD}

\section{Research Design}

This study employed 2 research designs. Firstly, One Group Pretest-Posttest Design. This is used to measure the students' opinion about the OLM method, and their motivation to learn mathematics. Secondly, Randomized Control-Group Pretest-Posttest Design. This procedure is used to measure the students' learning achievement in mathematics both in the experimental (E) and control (C) groups. The research designs are shown in Figure 2.

One Group Pretest-Posttest Design
Pretest Treatment Posttest

\begin{tabular}{|lll|}
\hline E: $\mathrm{T} 1$ & $\mathrm{X}$ & $\mathrm{T} 2$ \\
\hline
\end{tabular}

Randomized Control-Group Pretest-Posttest Design

Pretest Treatment Posttest

\begin{tabular}{|lll|}
\hline E: T1 & $\mathrm{X}$ & T2 \\
C: T1 & --- & T2 \\
\hline
\end{tabular}

Figure 2

Research designs used in the research

\section{Population and Sample}

This research was carried out at a public elementary school in Sumbersari sub-district, Jember district, East Java, Indonesia. The population was grade 4 students in classes $4 \mathrm{~A}$ and $4 \mathrm{~B}$ in the 2018/2019 academic year. The selection of grade 4 students was based on the consideration that the topic of geometry was studied by grade 4 students. In addition, according to the teacher, so far students have never been taught using the OLM method. Because class 4 only consisted of these 2 classes, all students were used as research samples. Next, the lottery was used to select, the 4A and 4B classes as the Experimental and control groups respectively. Each of the classes consists of 27 students, and the ages of the students ranged from 11 to 12 years. At the time of data collection, all students were involved in the process of learning mathematics on the topic of geometry. During 
the learning process, students are accompanied by a math teacher, researcher, and a school security officer, so that all data collection activities went well, smooth and successful.

\section{Method of collecting data}

The data collected in this study include (1) students' opinions about the OLM method, (2) students' motivation (LM), and (3) students' achievements (LAM). Furthermore, data collections were realised using questionnaires, observation, and test methods. Instruments (1), and (2) used for collecting data are questionnaires and observation sheet with a Likert scale, which has 5 answer options, namely SA (Strongly Agree), Agree (A), Neutral (N), Disagree (D), and Strongly Disagree (SD). These instruments were developed by Pambudi \& Hobri (2012). Where, a value of validity score $\mathrm{Va}=4.5$, and 4.4 (from max Skor 5.0) for instruments (1) and (2), while a value of $r=0.86$ and 0.88 implies the reliability for instruments (1) and (2). Instrument (3) is a mathematics learning achievement test developed by Sunardi, \& Sugiarti (2018), which is regarded as valid, when $\mathrm{Va}=4.3$ (from max Skor 5.0), and reliable when $\mathrm{r}=0.85$.

The hypotheses in this research are reported as follows

1. The application of OLM enhances the students' motivation to learn mathematics.

2. There is a significant positive correlation between students' motivation and their learning achievement of mathematics.

3. There is a significant difference between the learning achievement of students that learn mathematics with and without the use of the OLM method.

\section{Method of Analysing Data}

Data analysis in this study uses non-parametric statistics, because it does not require data normality. The data consists of students opinion data on the OLM method, observation data, and student learning achievement tests data. The scoring for both questionnaires and observation sheet are based on the following options $\mathrm{SA}=5, \mathrm{~A}=4$, $\mathrm{N}=3, \mathrm{D}=2$, and $\mathrm{SD}=1$. The scoring for students LAM includes a minimum and maximum score of 0 and 100 respectively. The data on students' opinion about OLM and students' motivation are stated on the frequency and percentage tables. A goodnessof-fit test of one-sample Kolmogorov-Smirnov test was employed to determine the uniformity of data in accordance with the following level of significant $\alpha=5 \%$.

To determine whether or not the students' motivation was triggered before and after using the OLM method, the difference between Pre-Test and Post-Test observations was determined using Wilcoxon Signed Ranks Test with level of significance $\alpha=5 \%$ (Sprent \& Smeeton, 2001; Ananda \& Fadhli, 2018).

In order to determine whether or not a significant correlation exists between data related to students' motivation to learn mathematics and their LAM, the Spearman rank correlation ( $\rho=r h o$ ) with level of significant $\alpha=5 \%$ was applied. The high and low correlation is determined by the value of $\rho$, and uses an interpretation as follows: 0.00 - 
0.20 (very low); 0.20-0.40 (low); 0.40-0.70 (moderate); 0.70-0.90 (high); and 0.90-1.00 (very high) (Sprent \& Smeeton, 2001; Ananda \& Fadhli, 2018).

Furthermore, to determine whether or not a significant difference exists between LAM realised from the experimental and control groups, the Mann-Whitney Test with level of significant $\alpha=5 \%$ was also utilized (Sprent \& Smeeton, 2001; Ananda \& Fadhli, 2018). To obtain accurate data analysis results, SPSS version 21 software was used.

\section{A brief description of the application of the OLM method on the topic of geometry for grade 4 elementary school students}

The research implementation included (1) giving pre-test of geometry learning achievements to all students in the experimental and control groups, (2) teaching those in the control group using conventional methods (using lectures method and only in the classroom) for two meetings, (3) teaching the students in the experimental group using the OLM method (in and outside the classroom) for two meetings, and observing the students' learning motivation, (4) giving post-test of geometry learning achievements to all students in the experimental and control groups, (2) distributing questionnaires to determine students' opinions about the application of the OLM method in the experimental group.

In the control group, the students were given time to learn and understand the material on concepts of triangles and their types, using mathematics textbooks, notebooks, and whiteboards during the first meeting. At the second meeting, they were asked to use the triangular concept application questions to solve the problems in the textbook. However, when they finished, the student representatives were welcomed to present their results on a whiteboard. To reduce the influence of the teacher factor on the achievement of this study, the teacher as a facilitator and motivator, thereby ensuring that all students have the textbooks mandated by the school, as well as carry out necessary instructions.

Conversely, in the experimental group, the students were given time to learn and understand the meaning of triangles and their types using mathematics textbooks, notebooks, and whiteboards, during the first meeting. At the second meeting, they were invited to the schoolyard to measure the height of the flagpole. In this case, the teacher is also a facilitator and motivator. The class is divided into 5 groups, and each consists of 5 to 6 members. Moreover, worksheets containing the task of measuring the height of the flagpole were distributed to all groups. In addition, they were also given a rolling meter, a right-angled triangle, and a rafiah rope. Each group was welcomed to measure the height of the flagpole using the concept of an isosceles right triangle. Immediately, after completing the experiment, all groups filled out the worksheets. After completing activities outside of classroom, the teacher invited all students into the class and asked the group representatives to present the results of their work. At the end of the lesson, the teacher gives them homework from their mathematics textbook. 


\section{FINDINGS}

\section{Data on students' opinion about the OLM method}

After learning geometry topic, all students in the experimental class were given a questionnaire to ascertain the students' opinions about the application of the OLM method. The results of filling out the questionnaire are shown in Tables 1 and 2.

Table 1

The data on students' opinion about the OLM method Degree of favorableness $(\mathrm{N}=27)$

\begin{tabular}{llllllllllll}
\hline \multirow{2}{*}{ No. } & $\mathrm{SA}$ & \multicolumn{3}{c}{$\mathrm{A}$} & \multicolumn{3}{c}{$\mathrm{N}$} & & $\mathrm{D}$ & \multicolumn{2}{l}{ SD } \\
\hline & $\mathrm{f}$ & $\%$ & $\mathrm{f}$ & $\%$ & $\mathrm{f}$ & $\%$ & $\mathrm{f}$ & $\%$ & $\mathrm{f}$ & $\%$ \\
\hline 1. & 9 & 33.33 & 17 & 62.96 & 1 & 3.70 & 0 & 0.00 & 0 & 0 \\
\hline 2. & 8 & 29.63 & 16 & 59.26 & 3 & 11.11 & 0 & 0.00 & 0 & 0 \\
\hline 3. & 11 & 40.74 & 14 & 51.85 & 2 & 7.41 & 0 & 0.00 & 0 & 0 \\
\hline 4. & 7 & 25.93 & 12 & 44.44 & 8 & 29.63 & 0 & 0.00 & 0 & 0 \\
\hline 5. & 6 & 22.22 & 19 & 70.37 & 1 & 3.70 & 1 & 3.70 & 0 & 0 \\
\hline 6. & 7 & 25.93 & 16 & 59.26 & 4 & 14.81 & 0 & 0.00 & 0 & 0 \\
\hline 7. & 9 & 33.33 & 11 & 40.74 & 5 & 18.52 & 2 & 7.41 & 0 & 0 \\
\hline 8. & 7 & 25.93 & 13 & 48.15 & 5 & 18.52 & 2 & 7.41 & 0 & 0 \\
\hline 9. & 9 & 33.33 & 15 & 55.56 & 3 & 11.11 & 0 & 0.00 & 0 & 0 \\
\hline 10. & 16 & 59.26 & 9 & 33.33 & 2 & 7.41 & 0 & 0.00 & 0 & 0 \\
\hline Total & 89 & & 142 & & 34 & & 5 & & 0 & \\
\hline
\end{tabular}


Table 2

Kolmogorov smirnov test of strongly agree (SA) and agree (A) on students' opinions about the OLM method

\begin{tabular}{llll}
\hline NO. & Statements of Questionnaire & $\begin{array}{l}\text { SA and A } \\
\text { Chosen }(\%)\end{array}$ & $\begin{array}{l}\text { Kolmogo- } \\
\text { rov Smirnov }\end{array}$ \\
\hline 1. & $\begin{array}{l}\text { This method reduces the feeling of boredom to learn } \\
\text { mathematics. }\end{array}$ & 96.30 & 2.406 \\
\hline 2. & $\begin{array}{l}\text { This method aids to develop students' communication } \\
\text { skills such as offering opinions, argumentation, and } \\
\text { writing a report of learning activities }\end{array}$ & 88.89 & 2.021 \\
\hline $3 . \quad \begin{array}{l}\text { This method causes students to be more active in the } \\
\text { teaching and learning processes. }\end{array}$ & 92.59 & 2.213 \\
\hline 4. $\quad \begin{array}{l}\text { This method develops students' creativity to solve the } \\
\text { problem. }\end{array}$ & 70.37 & 1.540 \\
\hline 5. $\quad \begin{array}{l}\text { This method improves students' skills to apply } \\
\text { mathematical concepts in solving certain problems in } \\
\text { reality. }\end{array}$ & 92.59 & 2.406 \\
\hline $6 . \quad \begin{array}{l}\text { This method serves as a nice recreation for the students } \\
\text { while studying mathematics. }\end{array}$ & 85.19 & 2.406 \\
\hline 7. & $\begin{array}{l}\text { This method offers an excellent and unforgettable } \\
\text { experience for students. }\end{array}$ & 74.07 & 2.117 \\
\hline 8. & $\begin{array}{l}\text { This method causes students to be knowledgeable about } \\
\text { the relationship between theories and the real situation. }\end{array}$ & 74.07 & 2.117 \\
\hline 9. & $\begin{array}{l}\text { This method develops the students' collaboration in } \\
\text { solving the problem. }\end{array}$ & 88.89 & 2.021 \\
\hline 10. $\quad \begin{array}{l}\text { This method makes the learning of mathematics more } \\
\text { interesting. }\end{array}$ & 92.59 & 3.079 \\
\hline & Average & 85.56 & \\
\hline
\end{tabular}

Based on table 2, it was concluded that $85.56 \%$ of the respondents agree and strongly agree with the application of the OLM method in the mathematics learning process, especially in the class 4 geometry topics. This means that majority of the students have a positive opinion concerning the application of the OLM method.

\section{Students' Motivation to Learn Mathematics}

During the first and second meetings, held in and outside the classroom, students' motivation in the experimental group before and after learning mathematics using the OLM method was observed. The data on students' motivation to learn mathematics is further analysed in tables 3 , and 4 . 
Table 3

Degree of favorableness of the students' motivation before learning mathematics using the OLM method

Degree of favorableness $(\mathrm{N}=27)$

\begin{tabular}{lllllllllll}
\hline \multirow{2}{*}{ NO. } & $\mathrm{SA}$ & & $\mathrm{A}$ & & $\mathrm{N}$ & & $\mathrm{D}$ & \multicolumn{3}{c}{$\mathrm{SD}$} \\
\cline { 2 - 11 } & $\mathrm{f}$ & $\%$ & $\mathrm{f}$ & $\%$ & $\mathrm{f}$ & $\%$ & $\mathrm{f}$ & $\%$ & $\mathrm{f}$ & $\%$ \\
\hline 1. & 6 & 22.22 & 11 & 40.74 & 8 & 29.63 & 2 & 7.41 & 0 & 0.00 \\
\hline 2. & 7 & 25.93 & 9 & 33.33 & 7 & 25.93 & 4 & 14.81 & 0 & 0.00 \\
\hline 3. & 8 & 29.63 & 10 & 37.04 & 6 & 22.22 & 3 & 11.11 & 0 & 0.00 \\
\hline 4. & 9 & 33.33 & 11 & 40.74 & 7 & 25.93 & 0 & 0.00 & 0 & 0.00 \\
\hline 5. & 6 & 22.22 & 12 & 44.44 & 5 & 18.52 & 4 & 14.81 & 0 & 0.00 \\
\hline 6. & 10 & 37.04 & 6 & 22.22 & 7 & 25.93 & 4 & 14.81 & 0 & 0.00 \\
\hline 7. & 9 & 33.33 & 10 & 37.04 & 5 & 18.52 & 3 & 11.11 & 0 & 0.00 \\
\hline 8. & 7 & 25.93 & 11 & 40.74 & 6 & 22.22 & 3 & 11.11 & 0 & 0.00 \\
\hline Total & 62 & & 80 & & 51 & & 23 & & 0 & \\
\hline
\end{tabular}

Table 4

Degree of favorableness of students' motivation after learning mathematics using the OLM method

\begin{tabular}{lllllllllll}
\hline Degree of favorableness (N=27) & & & & & & & & & & \\
\hline \multirow{2}{*}{ NO. } & SA & & A & & N & & SD & \\
\cline { 2 - 11 } & $\mathrm{f}$ & $\%$ & $\mathrm{f}$ & $\%$ & $\mathrm{f}$ & $\%$ & $\mathrm{f}$ & $\%$ & $\mathrm{f}$ & $\%$ \\
\hline 1. & 8 & 29.63 & 16 & 59.26 & 3 & 11.11 & 0 & 0.00 & 0 & 0.00 \\
\hline 2. & 11 & 40.74 & 14 & 51.85 & 2 & 7.41 & 0 & 0.00 & 0 & 0.00 \\
\hline 3. & 11 & 40.74 & 15 & 55.56 & 1 & 3.70 & 0 & 0.00 & 0 & 0.00 \\
\hline 4. & 10 & 37.04 & 13 & 48.15 & 4 & 14.81 & 0 & 0.00 & 0 & 0.00 \\
\hline 5. & 9 & 33.33 & 16 & 59.26 & 2 & 7.41 & 0 & 0.00 & 0 & 0.00 \\
\hline 6. & 11 & 40.74 & 13 & 48.15 & 3 & 11.11 & 0 & 0.00 & 0 & 0.00 \\
\hline 7. & 13 & 48.15 & 13 & 48.15 & 1 & 3.70 & 0 & 0.00 & 0 & 0.00 \\
\hline 8. & 10 & 37.04 & 15 & 55.56 & 2 & 7.41 & 0 & 0.00 & 0 & 0.00 \\
\hline Total & 83 & & 115 & & 18 & & 0 & & 0 &
\end{tabular}

The comparison between data on students' motivation before and after learning mathematics using the OLM method is shown in table 5. 
Table 5

The comparison between data on students' motivation before and after learning mathematics using the OLM method

\begin{tabular}{|c|c|c|c|}
\hline \multirow[b]{2}{*}{ NO. } & \multirow{2}{*}{$\begin{array}{l}\text { Item of observations } \\
\text { (Pre and Post Motivation) }\end{array}$} & \multicolumn{2}{|c|}{$\begin{array}{l}\text { SA and A } \\
\text { chosen }(\%)\end{array}$} \\
\hline & & Pre & Post \\
\hline 1. & $\begin{array}{l}\text { The students showed signs of curiosity and responsibility when } \\
\text { the teaching and learning processes started }\end{array}$ & 62.96 & 88.89 \\
\hline 2. & $\begin{array}{l}\text { The students seriously adhered to the teacher's explanation, when } \\
\text { the teaching and learning processes started }\end{array}$ & 59.26 & 92.59 \\
\hline 3. & $\begin{array}{l}\text { The students asked some questions during the teaching and } \\
\text { learning processes }\end{array}$ & 66.67 & 96.30 \\
\hline 4. & $\begin{array}{l}\text { The students were permitted to discuss the materials during the } \\
\text { teaching and learning processes }\end{array}$ & 74.07 & 85.19 \\
\hline 5. & $\begin{array}{l}\text { The students actively participated in the teaching and learning } \\
\text { processes }\end{array}$ & 66.67 & 92.59 \\
\hline 6. & $\begin{array}{l}\text { The students were interested in the material during the teaching } \\
\text { and learning processes }\end{array}$ & 59.26 & 88.89 \\
\hline 7. & The students understood the material & 70.37 & 96.30 \\
\hline \multirow[t]{2}{*}{8.} & $\begin{array}{l}\text { The prediction that students are able to solve real-life problems } \\
\text { after the teaching and learning processes were also improved }\end{array}$ & 66.67 & 92.59 \\
\hline & Average & 65.74 & 91.67 \\
\hline
\end{tabular}

Based on table 5, an average of $65.74 \%$ of students was motivated to learn mathematics, especially in geometry topic. However, in accordance with the PostMotivation results (after the intervention using OLM method), it was observed that on average $91.67 \%$ of students were highly motivated to learn the subject. This shows that student's learning motivation before and after learning mathematics was enhanced using the OLM method.

Table 6 shows a test statistic, called Wilcoxon signed ranks test adopted to determine the significant difference of the results stated in table 5 .

Table 6

Wilcoxon signed ranks test of related comparison between scores of Pre-Motivation, and Post-Motivation

\begin{tabular}{lllll}
\hline & & $\mathrm{N}$ & Mean rank & Sum of ranks \\
\hline $\begin{array}{l}\text { Post-Motivation }- \\
\text { Pre-Motivation }\end{array}$ & Negative Ranks & $0^{\mathrm{v}}$ & 0.00 & 0.00 \\
\cline { 2 - 5 } & Positive Ranks & $27^{\mathrm{w}}$ & 16.50 & 528.00 \\
\cline { 2 - 5 } & Ties & $0^{\mathrm{x}}$ & & \\
\hline & Total & 27 & & \\
\hline
\end{tabular}

$\mathrm{Z}=-4.961^{\mathrm{a}}$

Asymp. Sig. (2-tailed) $=0.000$

Notes:

$\mathrm{v}=$ Post-Motivation $<$ Pre-Motivation, $\mathrm{w}=$ Post-Motivation $>$ Pre-Motivation,

$\mathrm{x}=$ Post-Motivation=Pre-Motivation, and $\mathrm{a}=$ Based on negative ranks 
Table 6, shows that all observed items increased significantly from Pre-Motivation to the Post-Motivation results. Therefore, it was concluded that OLM method triggers the students' motivation to learn mathematics.

\section{Students' Learning Achievement of Mathematics in Geometry}

The students learning achievement data were obtained from the results of learning achievement tests (Pre and Post Test) on the materials based on triangles for class 4. The learning achievement scores that were awarded to students are from 0 to 100 . The data on students' learning achievement of mathematics (LAM) in geometry, from the experimental and the control groups are shown in Table 7.

Table 7

The data on students' learning achievement of mathematics in geometry

\begin{tabular}{llllll}
\hline Experiment Group (N=27) & Pre Test & Post Test & $\begin{array}{l}\text { Control Group } \\
(\mathrm{N}=27)\end{array}$ & Pre Test & $\begin{array}{l}\text { Post } \\
\text { Test }\end{array}$ \\
\hline Average & 63.15 & 79.33 & Average & 62.37 & 70.26 \\
St. deviation & 7.45 & 6.60 & St. deviation & 6.82 & 5.50 \\
Max & 87 & 100 & Max & 80 & 87 \\
Min & 50 & 70 & Min & 47 & 57 \\
\hline
\end{tabular}

In order to determine whether or not a significant relationship exists between students' motivation and their learning achievement, the data was tested using Spearman rank correlation $(\rho)$. The resume data on motivation and learning achievement as well as their correlation are shown in Table 8.

Table 8

The data and results of correlation between LM and LAM of students in the experimental group

\begin{tabular}{lllll}
\hline Item & $\begin{array}{l}\text { Pre } \\
\text { Motivation }(X 1)\end{array}$ & $\begin{array}{l}\text { Pre } \\
\text { Test }(Y 1)\end{array}$ & $\begin{array}{l}\text { Post } \\
\text { Motivation }(X 2)\end{array}$ & $\begin{array}{l}\text { Post } \\
\text { Test (Y2) }\end{array}$ \\
\hline Average & 30.67 & 63.15 & 34.78 & 79.33 \\
\hline St. deviation & 6.86 & 7.45 & 4.07 & 6.60 \\
\hline Max & 39 & 87 & 40 & 100 \\
\hline Min & 17 & 50 & 27 & 70 \\
\hline
\end{tabular}

In accordance with Table 8, the SPSS software was used, to obtain the coefficient $\rho$ for Pre-Test, and Post-Test which are 0.249, and 0.764, respectively. The coefficient $\rho=0.764$ is significant for $\alpha=1 \%$ and falls within the high level. Therefore, it was concluded that there is a highly significant positive correlation between students' motivation and their learning achievement after the OLM method was adopted. Based on the value $\rho=0.764$, it was reported that the OLM method contributes $58.37 \%$ (calculated from $\rho^{2}=0.764^{2}=0.5837$ ) to the improvement of student learning achievements. 
The next step is to determine whether or not the difference in students' learning achievement in the Pre-Test and Post-Test is significant. This test involves comparing differences of the mean ranks from the 2 samples (experimental and control group) using the Mann-Whitney Test. The complete results are shown in Table 9.

Table 9

Mann-Whitney test for comparison between scores realised from the learning achievement of experimental and control groups

\begin{tabular}{|c|c|c|c|c|}
\hline No. & Test statistics & $\mathrm{N}$ & Mean rank & Sum of ranks \\
\hline \multirow[t]{7}{*}{1.} & Pre-Test of Experimental Group & 27 & 27.67 & 747.00 \\
\hline & Pre-Test of Control Group & 27 & 27.33 & 738.00 \\
\hline & Total & 54 & & \\
\hline & Wilcoxon $\mathrm{W}=738.000$ & & & \\
\hline & Mann-Whitney $\mathrm{U}=360.000$ & & & \\
\hline & $Z=-0.079$ & & & \\
\hline & Asymp. Sig. (2-tailed) $=0.937$ & & & \\
\hline \multirow[t]{7}{*}{2.} & Post-Test of Experimental Group & 27 & 37.91 & 1023.50 \\
\hline & Post-Test of Control Group & 27 & 17.09 & 461.50 \\
\hline & Total & 54 & & \\
\hline & Wilcoxon $\mathrm{W}=461.500$ & & & \\
\hline & Mann-Whitney $U=83.500$ & & & \\
\hline & $Z=-4.195$ & & & \\
\hline & Asymp. Sig. (2-tailed) $=0.000$ & & & \\
\hline
\end{tabular}

Table 9 shows that two generalizations were obtained as follows. Firstly, in the Pre-Test, there is no significant difference (even at $\alpha=10 \%$ ) was detected between the learning achievement in mathematics from the experimental and control groups. Secondly, in the Post-Test, a significant difference (at $\alpha=1 \%$ ) was detected between the learning achievement in mathematics from the experimental and control groups. Based on both findings, it was concluded that there is a significant difference between the learning achievement of students that learnt mathematics with and without the OLM method. Therefore, the learning achievement of students that learnt mathematics with the OLM method tends to be better. These differences are due to the application of the OLM method in the teaching and learning processes.

\section{DISCUSSION}

The results showed that the students' opinions were positive in the sense of using the OLM method in learning geometry in schools. This is due to the fact that the OLM method has several advantages compared to the conventional ones, these includes the 
ability for reduce the feeling of boredom when learning mathematics; developing communication skill of students; increasing students' activeness in the teaching and learning processes; develops students' creativity in order to solve the problem; improves students' skill to apply mathematical concepts when solving some problems in reality; serves as a nice recreation for the students while they are studying mathematics; gives an excellent and unforgettable experience for students; makes students know about the relationship between theories and the real situation; develops the students' collaboration in solving the problem; and makes learning mathematics more interesting. The opinions or positive attitudes of these students indicate that the use of the OLM method to teach geometry has great potentials to enhance the students' motivation. This is in accordance with the studies carried out by Mygind (2007); Mata, et al. (2012), and Herges, et al. (2017).

Besides, students' motivation to participate in the learning process of geometry topics using the OLM method is evident in the observed results. Based on this, only $65.74 \%$ of students were motivated to learn mathematics. This increased significantly when the students studied outside the classroom. It was discovered that $91.67 \%$ of students were highly motivated to learn this subject. This shows that there is an increase in students' learning motivation before and after learning mathematics using the OLM method. The positive attitude of students is indicated by the willingness of students to follow all the learning processes with pleasure, cooperate with friends, and be responsible for doing the task of measuring the height of the flagpole well. Based on fiels notes, it can be said that the use of the OLM method, has become the subject of learning, and the students participate in several activities, such as listening to their teacher, asking questions, reading the book, answering questions, discussing with their peer, holding the borer rope, measuring the distance, writing notes, drawing vignette, walking to the flag pole, thinking, filling the students' worksheet, making reports, and doing class presentation. Therefore, it is evident that students learned mathematics in a meaningful manner, and not just mechanically. Moreover, the use of the conventional method, causes students to be perceived as the object of learning, where they sit and listen to the teacher, take notes, and ask questions. However, this is meaningless to the students (Fauzan, et al., 2013; Adamma, 2018; Damrongpanit, 2019).This is also in accordance with the results of research by Mygind (2007) that Outdoor Learning method offers unique opportunities learning because both physical activity and abstract thinking are combined.

The learning environment outside the classroom is one of the factors that increase student learning motivation. Based on fiels notes, it can be said that the atmosphere of students working on assignments outside the classroom is lively, all of them are enthusiastic, and have cheerful and happy faces. They tend to work while jogging and breathe fresh air, learning with a sense of joy and happiness, thereby enhancing their interest and motivation to learn mathematics. In contrast to the situations and conditions of students that were taught using conventional methods, they only work individually, therefore, assuming someone doesn't understand the material they are unable to answer the problem appropriately. They only learn by continuously sitting in chairs, and this leads to boredom, causing them to become less healthy, stressed out, and develop a negative perception of mathematics. Favorable situations and conditions are one of the 
factors that trigger motivation and better learning achievement in students that were taught with the OLM method, unlike the conventional methods. This is in accordance with the research carried out by Azid (2018) which stated that the cooperative learning model is effective in triggering positive attitudes and student learning achievements. It is also consistent with the studies carried out by Mygind (2007); Moss (2009); Waite (2011); Waite \& Pleasants (2012); Fägerstam \& Blom (2012); Fägerstam (2014); as well as Acar (2015), which stated that students that experience experiential learning under the fun, and enjoyable learning conditions, tend to incite positive attitudes and motivation to learn mathematics.

The increased of students' motivation to learn mathematics, thereby improving their learning achievements. This is clearly seen in the increase in test scores after students take part in learning with the OLM method; compared to the pre-test value. In the experimental class, there was an increase in the average test score of 16.18; while in the control class there was only an increase in the average test score of 7.89. From the results of the Mann-Whitney statistical test, it is also known that there is a significant difference between the learning achievements of students who study using the OLM method compared to students who do not use the OLM method. Based on the value $\rho=0.764$, it is shown that the OLM method contributes $58.37 \%$ to the improvement of student learning achievements. Although there are $41.63 \%$ of other factors that affect student learning achievements; but these results are a good start to continue to motivate students to study mathematics using the OLM method. Based on the description above, it is true that the use of the OLM method can increase student learning achievements of mathematics, including in geometry (Fägerstam \& Blom, 2012; Fägerstam, 2014; Adamma, et al., 2018; Damrongpanit, 2019; Pambudi, 2020; Sides \& Cuevas, 2020).

Based on the results of this study, it is necessary to carry out further researches, both in terms of the subject aspect, as well as the material. Because in this study only a few participants were involved, it is necessary to conduct research involving more subjects, so that more accurate results can be obtained. In addition, it is also necessary to research and develop modules for teachers that contain various materials that are suitable to be taught using the OLM method. For example, calculating the area and perimeter of a school yard; buying and selling food and beverages in the school canteen; and various other materials. The results of this study can be used as input for policy makers to include the OLM method in the curriculum, so that all teachers want to apply the OLM method in schools. It is hoped that after students are repeatedly taught using the OLM method, students will like mathematics more and more. The impact is that students' motivation and learning achievements of mathematics can be improved.

\section{CONCLUSION AND RECOMMENDATIONS}

Based on the results of the study, it can be concluded the following things. First, students' opinions were very positive and supported the application of the Outdoor Learning method in mathematics learning, including in geometry. Second, the Outdoor Learning method triggers the students' motivation to learn mathematics. Third, there is a highly significant positive correlation between students' motivation and their learning achievement after the Outdoor Learning method was adopted. The increased of students' 
motivation to learn mathematics, thereby improving their learning achievements. Fourth, there is a significant difference between the learning achievement of students that learnt mathematics with and without the Outdoor Learning method. This indicates that the learning achievement of students that learnt mathematics with the Outdoor Learning method tends to be better. Thus, it can be said that the Outdoor Learning method has a positive effect on elementary students' motivation and learning achievement in geometry.

In accordance with this, it is recommended that it is necessary to carry out further researches involving a large number of subjects. It is also necessary to conduct research to develop a teacher module to apply the OLM method in schools. Policy makers at the national education level need to develop a mathematics curriculum by requiring all teachers to apply the OLM method at all levels of education. The impact is that students' motivation and learning achievements of mathematics can be improved.

\section{REFERENCES}

Acar, H. (2015). Learning Environments for Children in Outdoor Spaces. In Procedia Social and Behavioral Sciences, (Vol. 141, pp. 846-853. Elsevier B.V. https://doi.org/10.1016/j.sbspro. 2014.05.147.

Acharya, B. R. (2017). Factors Affecting Difficulties in Learning Mathematics by Mathematics Learners. International Journal of Elementary Education, 6(2), 8-15. https://doi.org/10.11648/j.ijeedu.20170602.11.

Adamma, O. N. (2018). Influence of Extrinsic and Intrinsic Motivation on Pupils Academic Performance in Mathematics. Supremum Journal of Mathematics Education, 2(2), 52-59.

Akcakin, V. (2018). Teaching Mathematical Functions Using Geometric Functions Approach and its Effect on Ninth Grade Students' Motivation. International Journal of Instruction, 11(1), 17-32. https://doi.org/10.12973/iji.2018.1112a.

Ananda, R. \& Fadhli, M. (2018). Educational Statistics [in bahasa]. Medan: CV. Widya Puspita.

Anwar, K., \& Wardhono, A. (2019). Students' Perception of Learning Experience and Achievement Motivation: Prototyping English for Academic Purposes (EAP). International Journal of Instruction, 12(3), 271-288. https://doi.org/10.29333/iji.2019.12317a.

Ayub, N. (2010). Effect of Intrinsic and Extrinsic Motivation on Academic Performance. Pakistan Business Review, July 2010, 363-372.

Azid, N. (2018). Cooperative Learning: An Aproach for Teaching Mathematics in Public School. European Journal of Sosial Sciences Studies, 2(10), 122-133.

Bearnes, S. \& Ross, H. (2010). Journeys Outside the Classroom. Journal of Adventure and Outdoor Learning, 10(2), 95-109. https://doi.org/10.1080/14729679.2010.505708. 
Bilton, H. (2014). The Aims of Early Years Outdoor Education in England: A Conceptual and Empirical Investigation. International Journal of Education and Social Science, 1(3), 38-50.

Damrongpanit. (2019). From Modern Teaching to Mathematics Achievement: The Mediating Role of Mathematics Attitude, Achievement Motivation, and Self-Efficacy, European Journal of Educational Research, 8(3), 713-727. https://doi.org/10.12973/eu-jer.8.3.713.

Fägerstam, E. \& Blom, J. (2012). Learning Biology and Mathematics Outdoors: Effects and Attitudes in a Swedish High School Context, Journal of Adventure \& Outdoor Learning, 1-20. https://dx.doi.org/10.1080/14729679.2011.647432.

Fägerstam, E. (2014). High school teachers' experience of the educational potential of outdoor teaching and learning. Journal of Adventure Education and Outdoor Learning, 14(1):56-81. https://doi.org/10.1080/14729679.2013.769887.

Fauzan, A., Plomp, T., \& Gravemeijer, K. P. E. (2013). The development of an RMEbased geometry course for Indonesian Primary schools. In T. Plomp, \& N. Nieveen (Eds.), Educational design research - Part B. Illustrative cases (pp. 159-178). SLO: Netherlands institute for curriculum development.

Gafoor, K. A., \& Kurukkan, A. (2015). Why High School Students Feel Mathematics Difficult? An Exploration of Affective Beliefs. Conference paper in Pedagogy of Teacher Education: Trends and Chalanges, 2016, 23-27. https://doi.org/10.13140/RG.2.2.18880.12800.

Herges, R. M., Duffield, S., Martin, W., \& Wageman, J. (2017). Motivation and Achievement of Middle School Mathematics Students. The Mathematics Educator, 26(1), 83-106.

Kemdikbud RI. (2013). Standards of Processs of Primary and Middle Education [in bahasa]. Jakarta: Ministry of Education and Culture of Republic of Indonesia.

Kemdikbud RI. (2020). National Examination Results. [in bahasa]. https://pusmenjar.kemdikbud.go.id/hasil-un.

Kivkovich, N., \& Chis, V. (2016). Learning Abilities and Geometry Achievements. The European Proceedings of Behavioural Sciences EpSBS, 435-447. https://dx.doi.org/10.15405/epsbs.2016.12.53.

Lepper, M. R., \& Iyengar, S. S. (2005). Intrinsic and Extrinsic Motivational Orientations in the Classroom: Age Differences and Academic Correlates. Journal of Educational Psychology, 97(2), 184-196. https://doi.org/10.1037/0022-0663.97.2.184.

Mata, M. D. L., Monteiro, V., \& Peixoto, F. (2012). Attitudes towards Mathematics: Effects of Individual, Motivational, and Social Support Factors. Child Development Research, 2012, 1-10. https://doi.org/10.1155/2012/876028. 
Moss, M. (2009). Outdoor Mathematical Experiences: Constructivism, Connections, and Health. In: Clarke B; Grevholm B; Millman R. (eds) Tasks in Primary Mathematics Teacher Education. Springer, Boston, MA. Mathematics Teacher Education, 4(1), 263273. https://doi.org/10.1007/978-0-387-09669-8_17.

Mygind, E. (2007). A Comparison between Childrens' Physical Acitivity Levels at School and Learning in an Outdoor Environment. Journal of Adventure and Outdoor Learning, 7(2), 161-176. https://doi.org/10.1080/14729670701717580.

Nalevska, G.P., \& Kuzmanovska, M. (2020). Teaching Method as a Factor of Students' Learning Motivation. EDUCATION - Journal of Educational Research, 2(3-4), 40-50.

OECD. (2014). PISA 2012 Results in Focus: What 15-year-old know and what they can do with what they know. Paris: OECD.

OECD. (2016). PISA 2015 Result (Vol. 1): Excellence and Equity in Education. Paris: OECD.

OECD. (2019). PISA 2018 Results. https://www.oecd.org/pisa/ publications/pisa-2018results.html.

Pambudi, D. S., \& Hobri (2012). Learning Models of Mathematics using RME and PAKEM in Elementary School [in bahasa]. Jurnal Sekolah Dasar, 21(1), 74-88.

Pambudi, D. S., Budayasa, I. K., \& Lukito, A. (2020). The Role of Mathematical Connections in Mathematical Problem Solving. Jurnal Pendidikan Matematika, 14(2), 129-144. https://doi.org/10.22342/jpm.14.2.10985.129-144.

Pambudi, D.S. (2020). Exploration of Students Mathematical Connections with Negative Attitudes in Solving a Contextual Geometry Problem. Journal of Physics: Conference Series, 1663(1), 2031.

Richmond, D., Sibthorp, J., Gookin, J., Annarella, S., \& Ferri, S. (2017). Complementing classroom learning through outdoor adventure education: out-of-schooltime experiences that make a difference. Journal of Adventure Education and Outdoor Learning, 1-17. https://doi.org/10.1080/14729679.2017.1324313.

Ryan, R. M., \& Deci, E. L. (2000). Intrinsic and Extrinsic Motivations: Classic Definitions and New Directions. Contemporary Educational Psychology, 25, 54-67. https://doi.org/10.1006/ceps.1999.1020

Sembiring, R.K. 2010. Realistic Mathematics Education in Indonesian: Developments and Challenges [in bahasa]. Journal on Mathematics Education, 1(1), 11-16.

Sides, J. D., \& Cuevas, J. A. (2020). Effect of Goal Setting for Motivation, SelfEfficacy, and Performance in Elementary Mathematics. International Journal of Instruction, 13(4), 1-16. https://doi.org/10.29333.iji.2020.1341a.

Singh, K., Granville, M., \& Dika, S. (2002). Mathematics and Science Achievement: Effects of Motivation, Interest, and Academic Engagement. The Journal of Educational Research, 95(6), 323-332. https://www.jstor.org/stable/27542398. 
Sprent, I. P., \& Smeeton, N. C. (2001). Library of Congress Cataloging-in-Publication Data. Visit the CRC Press Web site at www.crcpress.com.

Sunardi, \& Sugiarti, T. (2018). Research Report. [in bahasa]. Jember: LP2M Unej.

Thomas, G. J. (2018). Effective Teaching and Learning Strategies in Outdoor Education, findings from two residential programmes based in Australia. Journal of Adventure and Outdoor Learning, 19(3), 1-14. https://doi.org/10.1080/ 14729679.2018.1519450.

Waite, S. (2010). Losing Our Way? The Downward Path for Outdoor Learning for Children Aged 2 - 11 Years. Journal of Adventure and Outdoor Learning, 10(2), 11126. https://doi.org/10.1080/14729679.2010.531087.

Waite, S. (2011). Teaching and Learning Outside the Classroom: Personal Values, alternative Pedagogies, and Standards. Education 3-13, 39(1), 65-82. https://doi.org/10.1080/03004270903206141.

Waite, \& Pleasants. (2012). Cultural Perspectives on Experiential Learning in Outdoor Spaces. Journal of Adventure and Outdoor Learning, 12(3), 161-165. https://doi.org/10.1080/14729679.2012.699797. 